\title{
The role of microbial mats in the movement of stones on playa lake surfaces
}

\author{
M.E. Sanz-Montero ${ }^{\mathrm{a}}{ }^{*}$, J.P. Rodríguez-Aranda ${ }^{\mathrm{b}}$ \\ ${ }^{a}$ Departamento de Petrología y Geoquímica, Facultad de Ciencias Geológicas (UCM), C/José Antonio Novais, 2, 28040 Madrid, Spain \\ ${ }^{\mathrm{b}}$ Departamento de Didáctica de las Ciencias Experimentales, Facultad de Educación (UCM), C/Rector Royo Villanova s/n, 28040 Madrid, Spain
}

a b s t r a c t

This paper sheds light into the debated mechanisms that move rocks across low gradient surfaces during storm episodes. Microbial mats are recognised to play a crucial role in sediment destabilisation and the subsequent motion of rocks in a playa lake from central Spain. Widespread countless scars are present on the playa lake sediment surface, each terminating at a stone, and/or a mound of overfolded fragments of microbial mats. All available objects, including cobble-sized stones, on the surface were transported for several metres leaving behind furrow-like tracks.

The starting point of the tracks was found underwater on a surface veneered by microbial mats poorly attached to the substrate. The flotation and transportation of the microbial upper layer by windgenerated water currents are suggested to be a critical element promoting the destabilisation and subsequent transportation of the attached sediment, including the rocks. The sudden exposure of bubble-separated sediment is also envisaged as a source of buoyancy required to lift out the rocks at the starting point of the tracks and to reduce the friction on the base of the rock. At the end of the tracks the rocks and the sediment mounds often overlap, which reveals that rocks were embedded and transported by sediment rafts across the playa lake surface.

The combination of the specific sedimentary and weather conditions involved in the transportation of rocks occurs periodically in mudflats. The implications are that this is not a local phenomenon, but rather, is a geographically widespread sedimentary process that may have occurred repeatedly throughout geological time. The effects of storm episodes can be inferred in ancient mudflat deposits by the assemblage of variablysized stones and microbial-mat related structures.

Keywords: Microbial mats, Sediment erodibility, Moving rocks, Rafting, Mudflats

\section{Introduction}

Objects that have left long trails behind them where they have moved across a flat surface are referred to as sailing stones, sliding stones, moving rocks, and playa scrapers. This geological process has been reported on a few modern playas which are mostly located in the USA, namely, Racetrack (Death Valley, California) (Kirk, 1952; Reid et al., 1995; Messina and Stoffer, 2000), Bonnie Claire Playa (Nevada)(Clements, 1952), Bonneville Playa (Pilot Valley, Utah) (Lines, 1979), and Alkali Flat (Big Smoky Valley, Nevada) (Wehmeier, 1986; Shaw and Bryant, 1997). In addition to nine playa lakes of the southwestern United States (Sharp and Carey, 1976), the stone tracks have been reliably reported on the Tunisian Sahara (Di Cesare and Pratelli, 1967) and South Africa (Eriksson et al., 1996).

The sliding stone activity has been noted since the beginning of the twentieth century in Death Valley playas (Clements, 1952; Kirk, 1952 and references therein) but is still considered an intriguing phenomenon

\footnotetext{
* Corresponding author.

E-mail addresses: mesanz@geo.ucm.es (M.E. Sanz-Montero), juanparo@ucm.es (J.P. Rodríguez-Aranda)
}

because the actual motion of the rocks has not been observed (Reid et al., 1995; Bacon et al., 1996; Messina and Stoffer, 2000; Lorenz et al., 2011). In addition, the process takes place in low gradient playa lakes and involves large stones (some reaching $320 \mathrm{~kg}$ ) that are able to move for many metres in different directions (Sharp and Carey, 1976).

There is no general consensus regarding the mechanisms which drive the moving rocks on playa surfaces. Three groups of mechanisms have been invoked to explain the phenomenon. The first hypothesis is that stones are blown by strong winds across wet playa surfaces (Clements, 1952; Kirk, 1952; Messina and Stoffer, 2000). Along those lines, Sharp and Carey (1976) monitored stone movement and concluded that moving of individual stones by wind is the basic process, under low frictional conditions, i.e., the surface should be a thin, slippery, superficial water-saturated layer. The second hypothesis suggests that stone tracks are produced by windblown ice rafts that reduce the reaction and friction forces on the bed (Stanley, 1955; Reid et al., 1995; Lorenz et al., 2011). Alternatively, Wehmeier (1986) argues that the driving force is the hydraulic energy of surface runoff.

Microbial mats are cohesive benthic microbial communities which colonise various environments, including the ephemeral (playa) saline lakes (Bauld, 1981). The prevalence of microbial mats and mat curls 


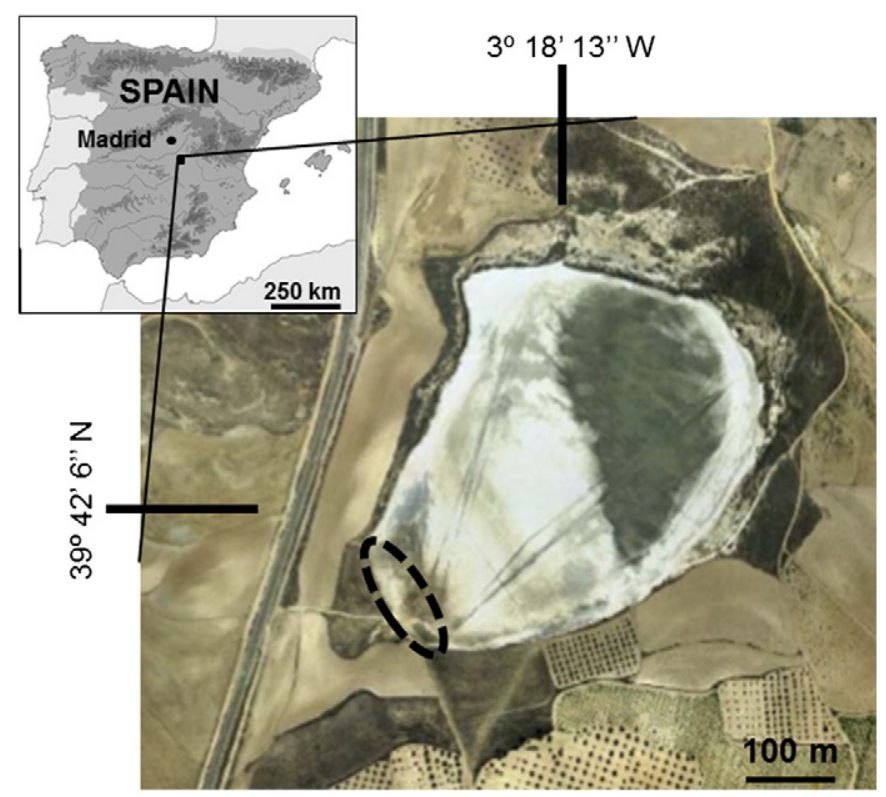

Fig. 1. Location of the Altillo Chica playa lake in central Spain. Rock tracks were found in the SW area of the playa (encircled).

has not gone unnoticed in the playas hosting sliding rocks (Kirk, 1952; Shelton, 1953; Sharp and Carey, 1976; Messina, 1988) but their potential involvement in the movement of the rocks has been neglected. Only some authors have recognised that the microbial mats play a role as a lubricant (Shelton, 1953; Messina, 1988; Lorenz et al., 2011).

In sedimentary successions, evidence of microbial mats is indicated by a variety of mat-related structures (e.g. Noffke et al., 2001; Schieber et al., 2007). Many of these structures are widely recognised in the playa lakes of the La Mancha wetland area, in central Spain (Sanz-Montero et al., 2012; Sanz-Montero et al., 2013). One playa lake (Altillo Chica) contains tracks across its sediment surface produced by the movement of rocks. The tracks were newly formed when first observed, which accounted for the very good preservation of the sedimentary structures and formative conditions in the playa. This provided a good opportunity to study comprehensively the unaltered variables affecting the movement of rocks and the associated sediment. Observations from the Altillo Chica playa furnish valuable insight into the crucial role that microbial mats play in the movement of rocks and sediment erodibility under the influence of wind-generated water currents. In addition, the presence of stone tracks on the Altillo Chica playa provides a new record of this type of sedimentary structures in the Mediterranean area. This suggests that the movement of rocks on smooth and flat surfaces is, geographically speaking, more widespread phenomenon than previously thought.

\section{Material and methods}

Although fieldwork in the Altillo Chica playa (Fig. 1) h a s b e e $\mathrm{n}$ conducted regularly since December 2009, the occurrence of "scrapers" on its surface had not been observed until 28 December, 2012. Since then to June 2013, the site has been visited four times more to monitor the evolution of the tracks. One of these visits was conducted to analyse the potential effects of an explosive cyclogenesis event (strong storm) that took place during January 2013. Sampling and sedimentological observations including orientation of the tracks and related structures have been mainly focused on the southwestern part of the playa where the tracks were more abundant (Fig. 2A). The physical, biological and geochemical properties of both variables that affect sediment erodibility, sediment and water (Grabowski et al., 2011) were tested.

In the field, water temperature, salinity, total dissolved solids (TDS) and $\mathrm{pH}$ measurements were taken with a Hanna HI 9828 Sampler. Water samples were collected in duplicate directly from the playa lake. In order to examine the chemical composition of water, major ions (Table 1) were analysed in filtered samples by ion chromatography and spectrophotometry (Museo Nacional de Ciencias Naturales, Madrid).

Twelve samples comprising sediment and microbial mats were collected mainly in the SW area of the Altillo Chica. The mineralogy of samples was determined by XRD of powdered specimens on a Philips X-ray diffraction system. Dry mass was calculated using loss on ignition at $450{ }^{\circ} \mathrm{C}$ for $10 \mathrm{~h}$ to estimate the content of the total organic carbon (TOC) of four subsamples by subtracting the difference between the total carbon (TC) content and inorganic carbon (IC) content (Table 2). For high-resolution textural analyses of sediment, uncoated specimens were observed in an environmental scanning electron microscope (SEM-ESEM) provided with $\mathrm{X}$-ray energy dispersive spectroscopy.

The standard climate values (temperature, precipitation, wind frequencies, directions, and speed) recorded during the September 2012January 2013 period at two climate stations (Ocaña and Tembleque) that are located $27.8 \mathrm{~km} \mathrm{~N}$ and $17.4 \mathrm{~km} \mathrm{~W}$ of the study playa, respectively, were provided for the Spanish Meteorological Agency (AEMET). Wind rose graphs showing the distribution of winds at the Ocaña station and the orientation of representative track-segments have been plotted by using the WRPLOT View programme (Fig. 3).
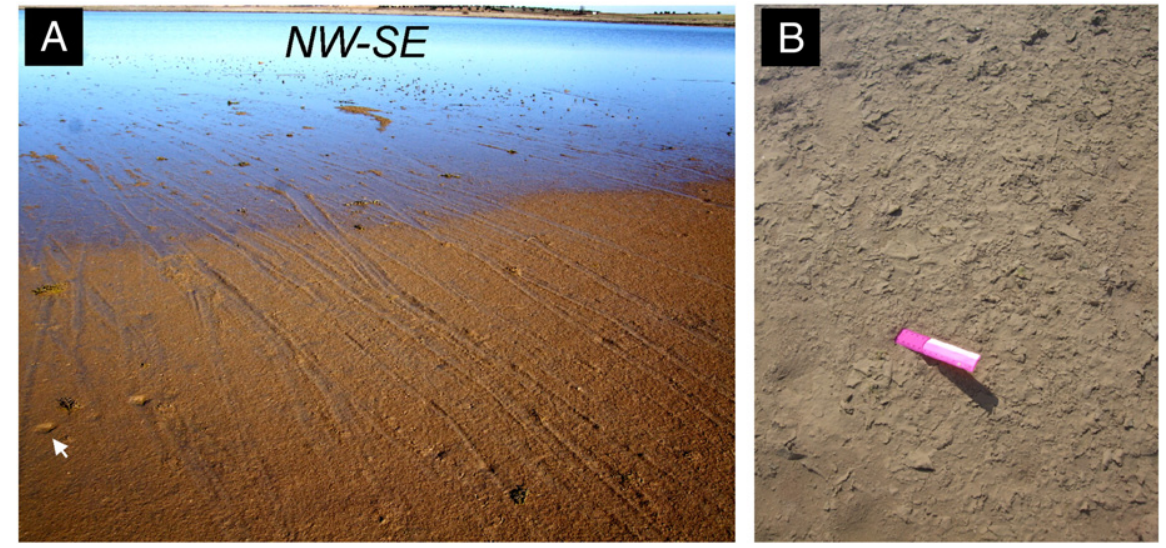

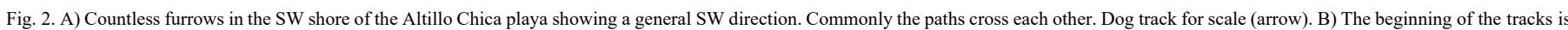
found in the ponded area with an average water depth of $4 \mathrm{~cm}$. 
Table 1

Chemical composition of water in the Altillo Chica playa.

\begin{tabular}{lrr}
\hline & ppm & meq/L \\
\hline $\mathrm{Cl}^{-}$ & 3402 & 95.26 \\
$\mathrm{SO}_{4}^{2-}$ & 3459 & 72.64 \\
$\mathrm{HCO}_{3}^{-}$ & 67 & 10.99 \\
$\mathrm{Ca}^{2+}$ & 379 & 18.95 \\
$\mathrm{Mg}^{2+}$ & 967 & 79.29 \\
$\mathrm{Na}^{+}$ & 1344 & 57.79 \\
$\mathrm{~K}^{+}$ & 92 & 2.35 \\
\hline
\end{tabular}

\section{The study site}

\subsection{Geological setting}

Altillo Chica is one of the playa lakes that form on the La Mancha wetland in central Spain (Fig. 1). Altillo Chica is a $0.46 \mathrm{~km} \times 0.42 \mathrm{~km}$ playa at an elevation of $681 \mathrm{~m}$, which is flooded in the wet season, occupying a Quaternary flat-bottomed depression in Neogene sedimen-tary rocks. Palaeozoic slate and metaquartzite hills are also present in the watershed. The "scraper" phenomenon takes place in the SW part of the playa that represents less than a quarter of its total surface. The SW margin gently slopes to the flat playa surface in the centre. Over the winter the maximum water depth was $8 \mathrm{~cm}$, although the average depth is lower than $5 \mathrm{~cm}$ (Fig. 2B). However, it has been observed that the advance and retreat of lake waters due to wind stress can expose or cover many square metres of the playa in a short time.

\subsection{Water chemistry}

Over the study period, chlorides, sulphates and bicarbonates were dissolved within Altillo's waters (Table 1). The playa lake water had a concentration of about $9.7 \%$ TDS with a $\mathrm{pH}$ of 8.6. Ionic composition was (meq/L): $\mathrm{Mg}^{2+} \mathrm{NNa}$ ${ }^{+} \mathrm{NCa}^{2+} \mathrm{NK}^{+}$and $\mathrm{Cl}^{-} \mathrm{NSO}_{4} \mathrm{NHCO}_{3}^{-}$. E $1 \mathrm{e}$ v a t e d ${ }^{2}$ levels of $\mathrm{SO}_{4}^{-}$in the lake are due to the abundance of Miocene gypsum rocks in the watershed.

\subsection{Climate}

The local climate of the area is semi-arid with an average temperature of $14.3^{\circ}$ $\mathrm{C}$ and a mean annual precipitation between 360 and $500 \mathrm{~mm}$, although with significant seasonal fluctuations (Pérez González and Sanz, 1998). The summer months are very dry. This, together with an average lake evaporation rate of about $1300-1600 \mathrm{~mm} / \mathrm{yr}$, favours the complete desiccation of the playa lake (Figs. 1, $4 \mathrm{~A}-\mathrm{B})$. The playa is inundated when fall and spring precipitation in and around the surrounding landscape supply sufficient water.

The playa was dry and covered by salts (mainly gypsum, magnesium sulphates and halite) from May to September 2012. We have studied in detail climatological data (wind, temperature and precipitation) for the September 2012-January 2013 period, to determine the time of

Table 2

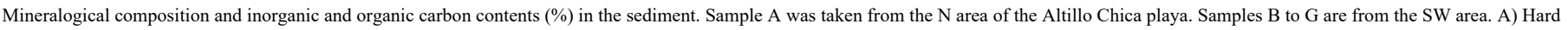
sediment without microbial mats. B and C) Upper layer of the microbial mats from a flooded and an exposed area, respectively. D) Soft sediment underlying microbial mats. E and F) Sediment forming the substrate of a flooded and an exposed track, respectively. G) Folded mat pile shown in Fig. 10A.

\begin{tabular}{|c|c|c|c|c|c|c|c|}
\hline $\begin{array}{l}\text { Mineral and } \\
\text { carbon content }\end{array}$ & $\begin{array}{l}\text { A } \\
\text { Sediment } \\
\text { (N area) }\end{array}$ & $\begin{array}{l}\text { B } \\
\text { Microbial mat } \\
\text { (flooded area) }\end{array}$ & $\begin{array}{l}\text { C } \\
\text { Microbial mat } \\
\text { (exposed area) }\end{array}$ & $\begin{array}{l}\text { D } \\
\text { Sediment underlying } \\
\text { microbial mats }\end{array}$ & $\begin{array}{l}\text { E } \\
\text { Substrate } \\
\text { (flooded track) }\end{array}$ & $\begin{array}{l}\text { F } \\
\text { Substrate } \\
\text { (dry track) }\end{array}$ & $\begin{array}{l}\text { G } \\
\text { Wrinkled } \\
\text { mat pile }\end{array}$ \\
\hline Gypsum & 72 & 35 & 16 & 66 & 49 & 34 & 48 \\
\hline Quartz and feldspars & 8 & 26 & 46 & 8 & 22 & 38 & 27 \\
\hline Phyllosilicate & 12 & 28 & 18 & 15 & 10 & 15 & 13 \\
\hline Calcite & 8 & 11 & 20 & 19 & 19 & 13 & 12 \\
\hline Inorganic C & & 2.8 & 2.7 & & 1.9 & 2.4 & \\
\hline Organic C & & 2.6 & 3.8 & & 0.7 & 0.9 & \\
\hline
\end{tabular}
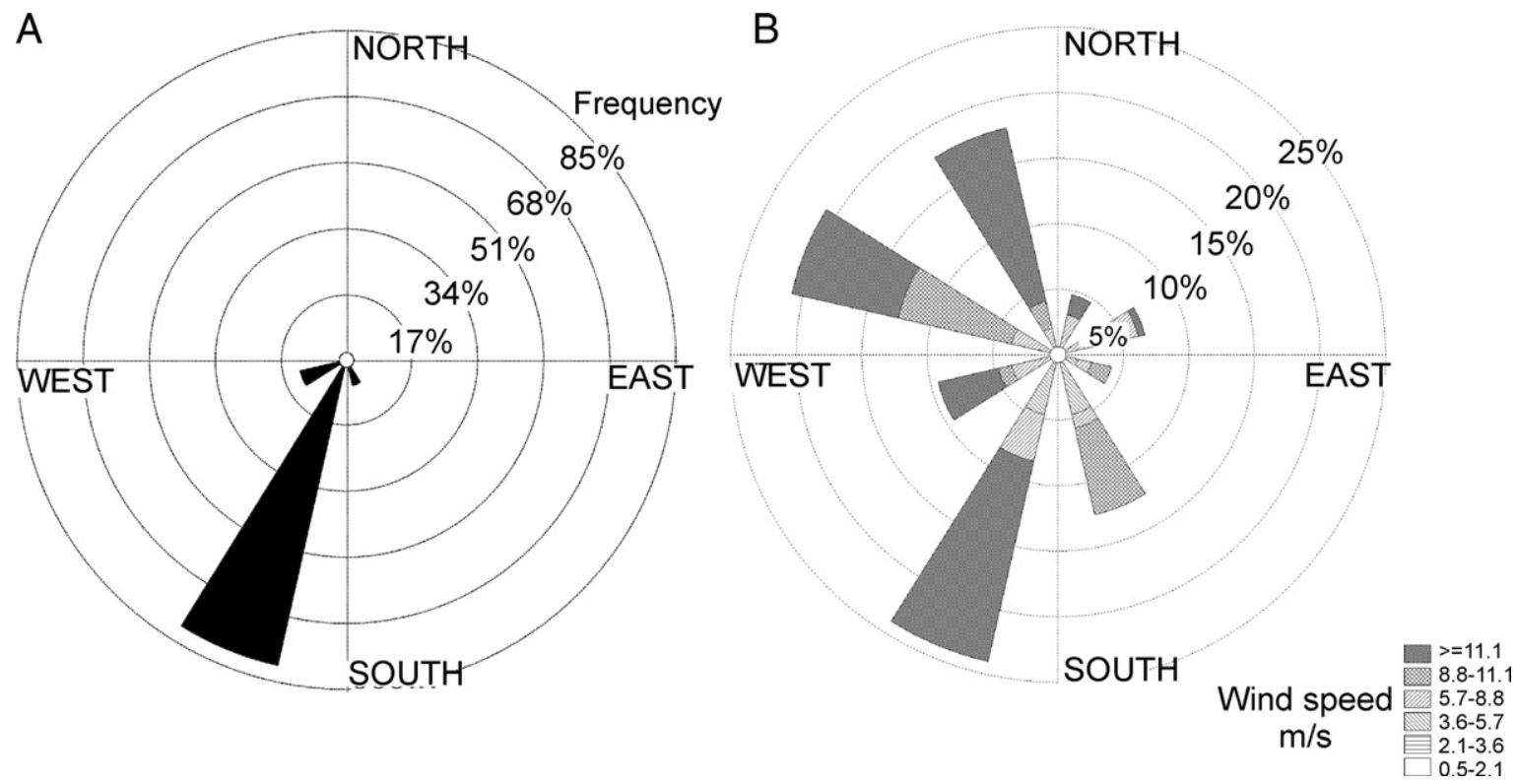

Fig. 3. Wind rose graphs. A) Frequency of representative segments of tracks. B) Distribution of winds for the 7-14 November period. 

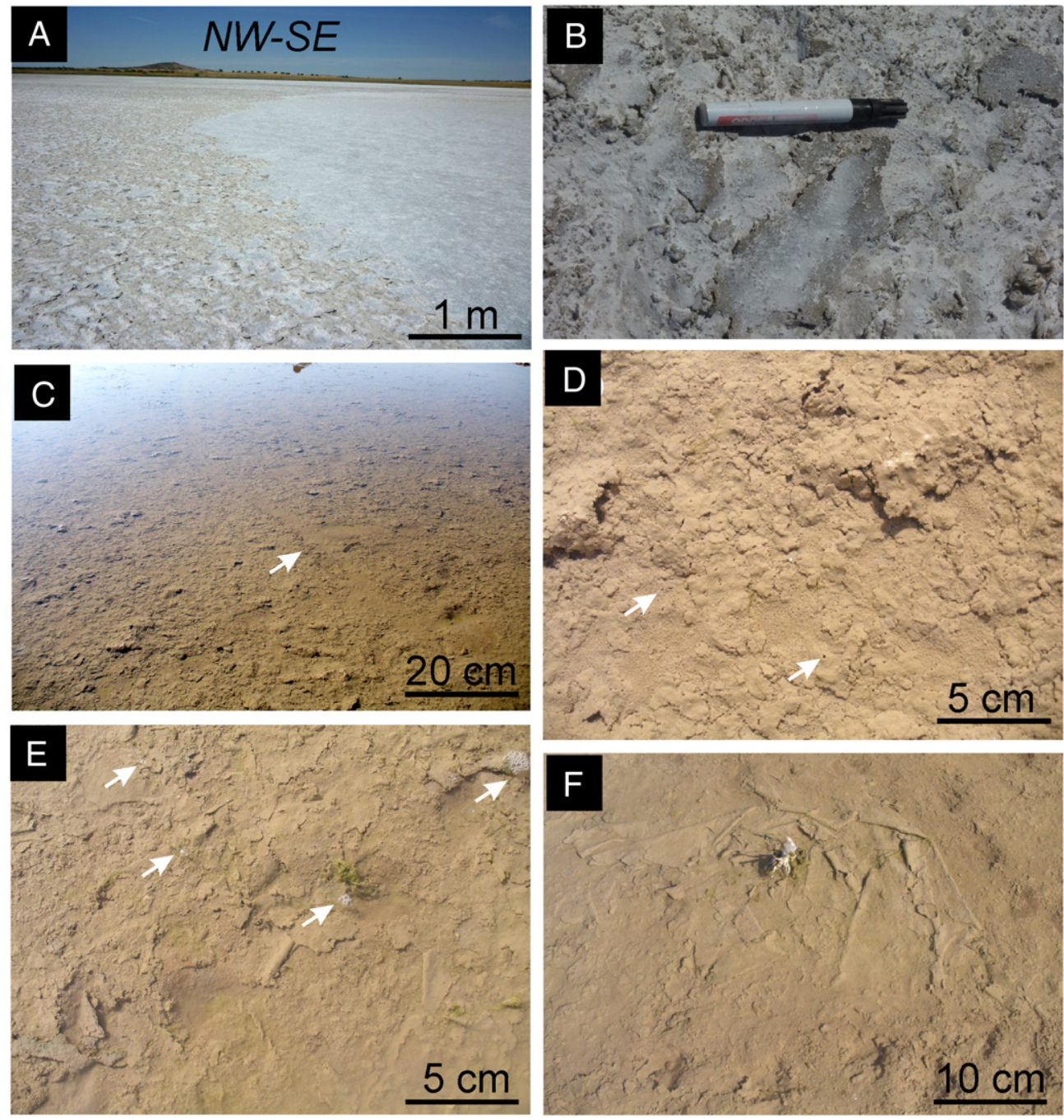

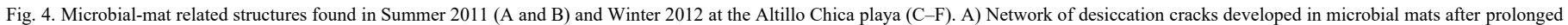

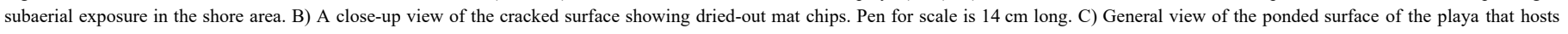
microbial mats that are loosely attached to the underlying surface and show irregular cracks. A trail left by a transported object is shown by an arrow.

D) Close-up view of microbial mat portions that are buoyed by attached gas bubbles. Small circular holes are the exit points of gas bubbles from the substrate. E) Thin microbial mats are torn and show flipped-over edges. Some freshly produced bubbles are arrowed. F) Mat deformation structure associating flipped-over edges and folds.

formation of the traces. The sedimentary structures and directions of the tracks indicate that the traces were formed episodically under prevailing rain and wind events. These circumstances occurred over the area during the two first weeks of November 2012. On November 3rd the monthly maximum 1-day precipitation was recorded as $42 \mathrm{~mm}$. The main autumn rainfall occurred between November $2 \mathrm{nd}$ and $11 \mathrm{th}$ (100 $\mathrm{mm}$ of precipitation). For this period, prevailing winds blew to the SW, but significant winds normally come from all directions (Fig. 3B). The wind gusts reached $15.5 \mathrm{~m} . \mathrm{s}^{-1}$ (November 9th). The observed wind patterns at that time of the year are consistent with long-term climate records for the study area (Pérez González and Sanz, 1998). Within the November-December period, the absolute minimum temperature was $-4.6{ }^{\circ} \mathrm{C}$ and during twelve days it was below $-3{ }^{\circ} \mathrm{C}$. However, we have observed that water did not freeze at $-3.2{ }^{\circ} \mathrm{C}$ and $-3.4{ }^{\circ} \mathrm{C}$, the minimum temperatures recorded in the playa during the 28th and the 29th of December, respectively. Despite the negative values, the water does not freeze due among others to the diurnal variations of temperature in the area, the water's salt content, and the water's high specific heat capacity. In fact, the water temperature measured at noon was over $14{ }^{\circ} \mathrm{C}$, whereas the maximum atmospheric temperature was 9.7 ${ }^{\circ} \mathrm{C}$.
We analysed in the field the effects of an explosive cyclogenesis event that took place during the 19th of January 2013. It was observed that the heavy precipitation and strong winds (up to $15.3 \mathrm{~m} . \mathrm{s}^{-1}$ ) that characterised that event did not move the rocks from their positions on the SW margin of the lake. However, parts of the tracks were slightly eroded.

\subsection{Sedimentological and biological properties}

Except for the SW area where the stone tracks are located, the playa surface was devoid of cyanobacterial film during the study period. The sedimentary material composing the surface without biological films was quite firm so that a person walking sank down not more than $1 \mathrm{~cm}$. Mineralogical determinations (Table 2A) show that the fine-grained sediment of this area consists chiefly of gypsum (up to $70 \%$ ), phyllosilicate clays (less than $15 \%$ ), and calcite. Quartz and feldspar grains account for less than $8 \%$.

In the SW part of the playa, the surface hosted a thin veneer of photosynthetic microbes forming a greenish microbial mat. The mats cover blackish sediment with evidence for sulphate reduction. The uppermost 8 $\mathrm{cm}$ of the SW playa sediment was soft and slippery (our 
footsteps sprayed the mud onto the side of our boots). In previous field work, it was observed that the surface of the playa showed a variety of microbial-mat related structures, including desiccation polygonal forms, mat chips (Fig. 4A-B), and domes (Sanz-Montero et al., 2012; Sanz-Montero et al., 2013). During the study period, the microbial mats were seen to be loosely attached to their substrate because gases produced by microorganisms accumulate in bubbles below them and cause their flotation (Figs. 2B, 4C-D). Detachment may follow the boundaries of previous cracks and favours the development of defor-mation structures like tears, folds, curls, and flipped-over edges (Fig. 4E-F). Portions of microbial mats showed detachment and transportation over variable distances leaving behind smooth scars (Fig. 4C) that commonly are associated with rock trails.
Fig. 5 shows the environmental scanning electron microscope (SEMESEM) images of the microbial mat and the underlying sediment. In the upper layer of the mats, abundant benthic diatoms and cyanobacterial filaments embedded by exo-polymeric substances (EPS) form a tight framework in which both detrital grains and mineral precipitates are firmly held (Fig. 5A-E). The cohesive properties of this type of framework are even evident in the folded parts of the mat (Fig. 5D). Diatoms commonly occur associated with the EPS threads (Fig. 5B), which suggest that the algae excrete the EPS. Oscillatoria and Anabaena are the dominant types of cyanobacteria found in the playa (Guerrero and De Wit, 1989). Mineralogical analyses of the microbial mats (Table 2, B -C) indicate that the mineral precipitates are gypsum (up to 35\%) and calcite accompanied by minor celestite (Fig. 5B), halite,
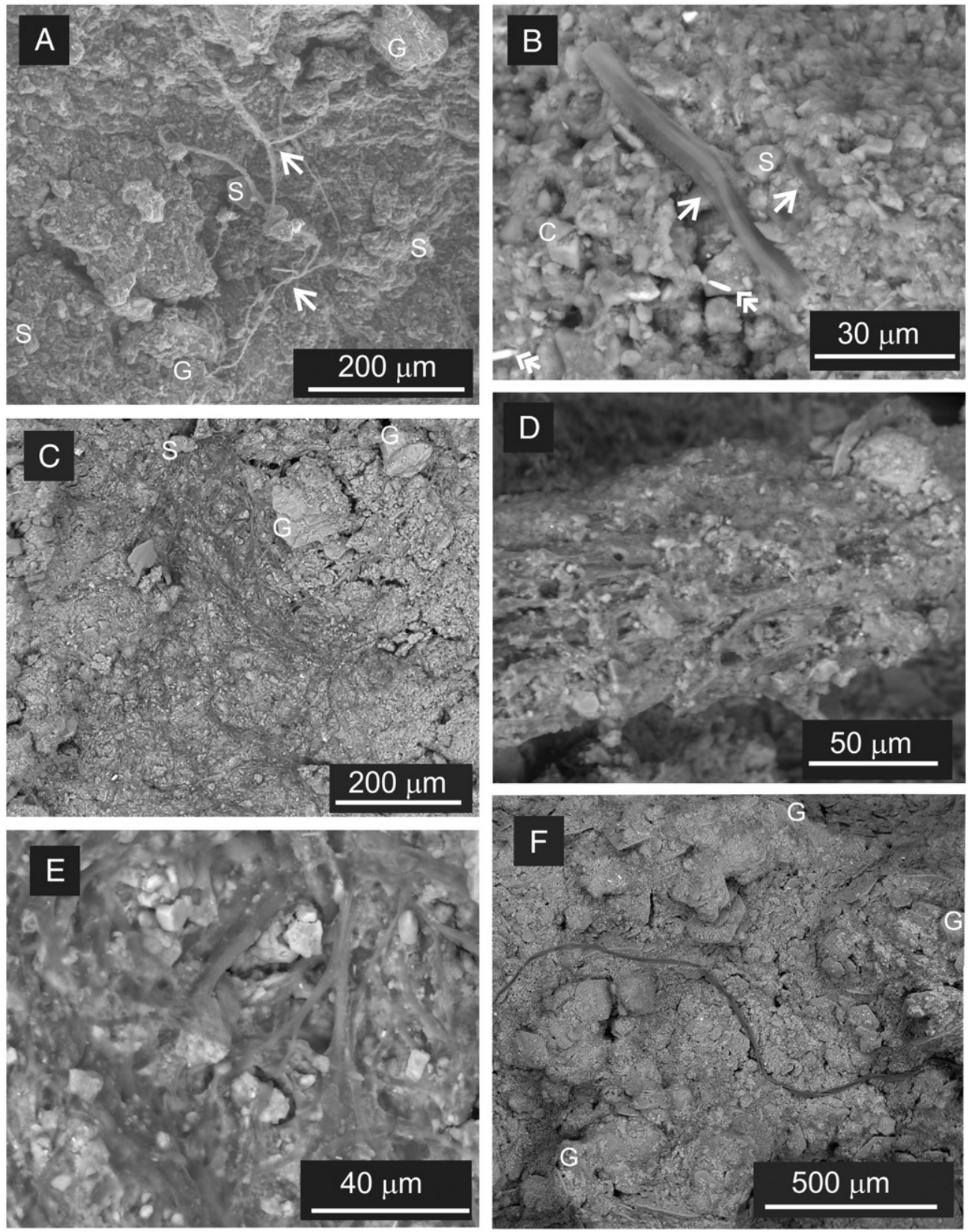

Fig. 5. SEM-ESEM images of the microbial mat (A-E) and the underlying sediment (F) from Altillo Chica playa mainly composed by gypsum (G), calcite (C) and silicate grains (S). A) Cyanobacterial filaments (arrow) can be seen forming a net in the mat. B) Benthic diatoms (arrow) abound in the upper part of the mat. Celestite (double headed arrow) is a common mineral precipitate. C) EPS threads are seen forming a tight frame in which mineral precipitates and detrital grains are firmly held. D) In the flipped-over edges, the cohesiveness of the microbial mat is also evident. E) Tight network of EPS threads and bound minerals. F) Organic filaments are rarely seen on the gypsum-rich sediment underlying the biofilms. 
and Mg-sulphates. Up to $300 \mu \mathrm{m}$ long gypsum crystals are deeply corroded (Figs. 5A, C). Silt-sized detrital grains are mainly quartz, with minor feldspars, micas, and heavy minerals. The carbon content in the microbial mat-bearing samples is mostly in the organic form (ranging from $2.6 \%$ to $3.8 \%$, Table $2 \mathrm{~B}-$ C).

In the sediment underlying the microbial mats (Fig. 5F, Table 2D), the content of organic carbon is much lower $(0.7-0.9 \%)$, which is consistent with the scarcity of organic filaments in this layer. In contrast, the size and composition of the minerals in the mats and the underlying sediment are not significantly different. Gypsum crystals underlying the microbial mats, which account for up to $66 \%$, do not show signs of significant dissolution. In general terms, the content in detrital silicates increases from the centre to the margins of the playa, whereas the gypsum crystals decrease.

\section{Trace description}

Widespread over a $560 \mathrm{~m}^{2}$ surface of the playa are countless scars, each terminating with a stone and/or a mound including microbial mat portions (Figs. 6-10). All available pebble and cobble-sized stones
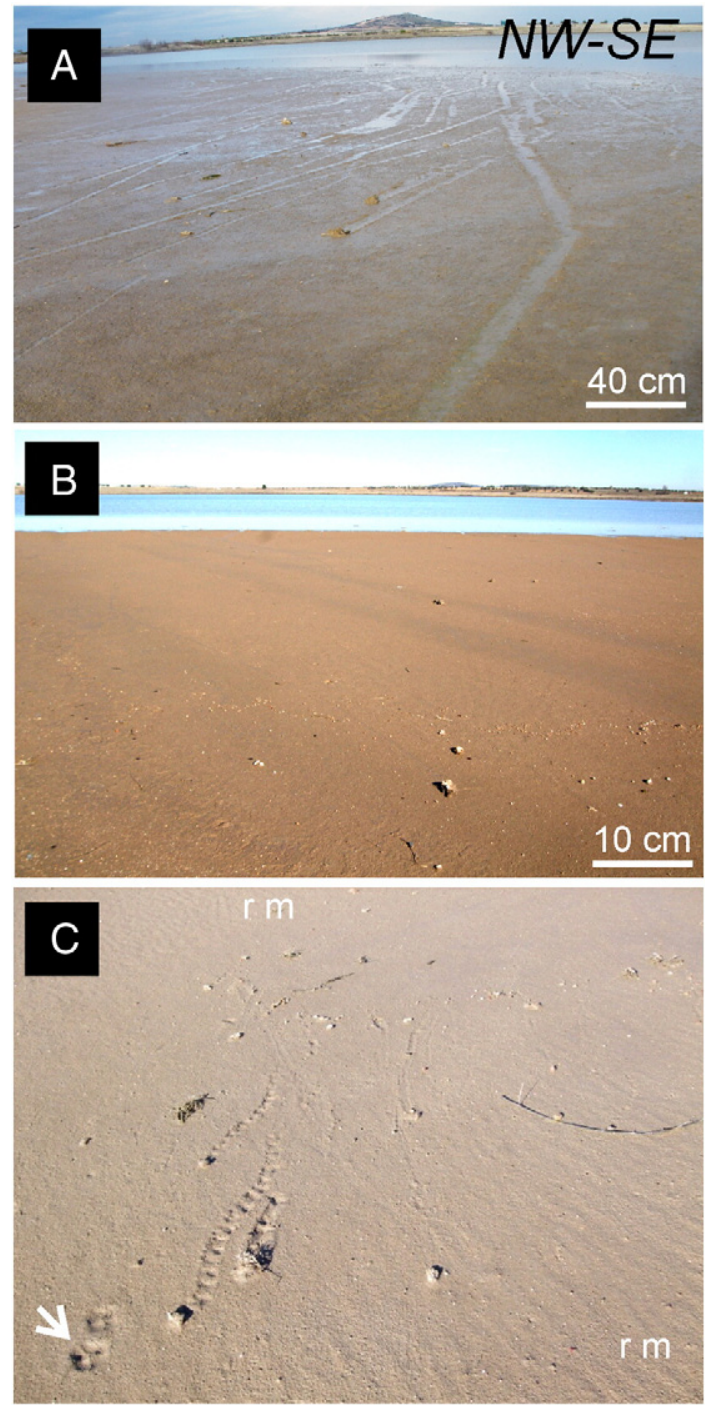

Fig. 6. Sedimentary structures along the SW shore of the Altillo Chica playa. A) Smooth and furrow-like tracks terminating at an object occur in a high density on the wet surface of the playa B) Upper limit of the flooded area was identified by the aligned stones and twigs that accumulated along the waterline during a stormy episode. C) Close-up view of the line of rocks showing multidirectional ripple forms (rm) associated with roll marks and furrows left by stones. Dog track for scale (arrow). (or some other tools) on the SW playa surface moved for several metres leaving behind furrow-like tracks (Figs. 2A, 6A).

Although tracks are multidirectional, they show a predominant trend from $\mathrm{NE}$ to SW with most of their segments $(80 \%)$ oriented between $180^{\circ}$ and $225^{\circ}$ (Fig. 3A). The traces extend for up to $25 \mathrm{~m}$ on the shore between the flooded playa lake floor and an uneven line of rocks and other objects (mainly twigs) as evidence of a former water line (Fig. 6B). The shore bed shows trains of small-scale ripples oriented in different directions, which commonly are perpendicular or oblique to the direction of the trails (Fig. 6C). Landwards from the playa lake margin, small "scrapers" are associated with up to $1 \mathrm{~m}$ long roll marks produced by gravel-sized stones (Fig. 6C).

For descriptive purposes we have differentiated two types of traces: 1) trails commonly ending with mounds of dragged mats and sediment (Fig. 7) and 2) tracks ending with rocks (Figs. 8, 9). The two previous types can overlap and occur simultaneously as displayed in Fig. 10.

\subsection{Dragged mats and sediment tracks}

At the end of many of the furrow-like trails are greenish mounds that are up to $1 \mathrm{~m}$ wide and $15 \mathrm{~cm}$ high (Fig. 7). The transported mounds are found at the end of generally smooth and cone-shaped scars, commonly much narrower at the start than at the end (Fig. 7A, C) and with several branching trails (Fig. 7D). These trails are commonly straight or gently curved traces between a few centimetres and $10 \mathrm{~m}$ in length so they may have had dimensions of several $\mathrm{m}^{2}$. The trails start in the flooded area covered with detached mats (Fig. 7B) and are oriented $\mathrm{N} 220^{\circ} \mathrm{W}$ outwards. In many places there is a striking similarity in the marks produced by neighbouring mat piles that are spaced apart by less than $1 \mathrm{~m}$ ( Fig. 7C-D). The mounds consist of dragged mats and variable amounts of the underlying sediment (Fig. 7D-F). In addition, twigs, uprooted weeds, and variably-sized rock fragments may be embedded in the mounds.

A type of mound consists solely of mat fragments that are folded over many times with folds oriented in the same direction (Fig. 7E). In contrast, other massive mounds are composed mostly of mat clasts and black mud eroded from the substrate (Fig. 10B, D). In some mounds, folded portions of mats accumulated in the front with the massive sediment in the back and/ or the top of the mound (Fig. 7F).

\subsection{Rock tracks}

The rocks that made the tracks are of variable shape and size (Figs. $6 \mathrm{~B}, 8$ ), the larger ones with an average dimension of $4 \mathrm{~cm}$ and a maximum of $16 \mathrm{~cm}$. The rocks consist of angular to subangular metaquartzite and quartz clasts, derived from the Palaeozoic rocks, as well as of angular to subangular chert and carbonate rock fragments, derived from the Miocene terrains. Smaller, 1-3 cm, and rounded metaquartzite and quartz fragments (Pliocene) are also abundant at the end of the trails (Fig. 6B-C). Other objects, such as bricks ( $25 \mathrm{~cm}$ long), twigs, weeds, and bottles, also are found at the end of trails.

Descriptions and interpretations of the morphological features of rock trails by different authors in other playa lakes, mostly in Racetrack Playa of the Death Valley area (see references above) generally apply to the Altillo Chica tracks. Thus, in this description we follow common terms and concepts used in those papers. However, unlike what was observed in other places, traces begin under water in this playa (Figs. 2, 6A). In some cases, it is even possible torecognis the sub merged origin area of the transported rocks in the zone where mats float and are detached from the underlying sediment (Fig. 8A-C). Tears, flipped-over edges, incipient folds, and porosity created by bullesare the structures pevailing in this area.

Common features of the traces are illustrated in Fig. 9 showing a long path with various segments left by one of the rocks (see Fig. 8F). At the submerged start of the trails are depressions or sitz marks. The depressions are deeper than the trails and are surrounded by sediment 

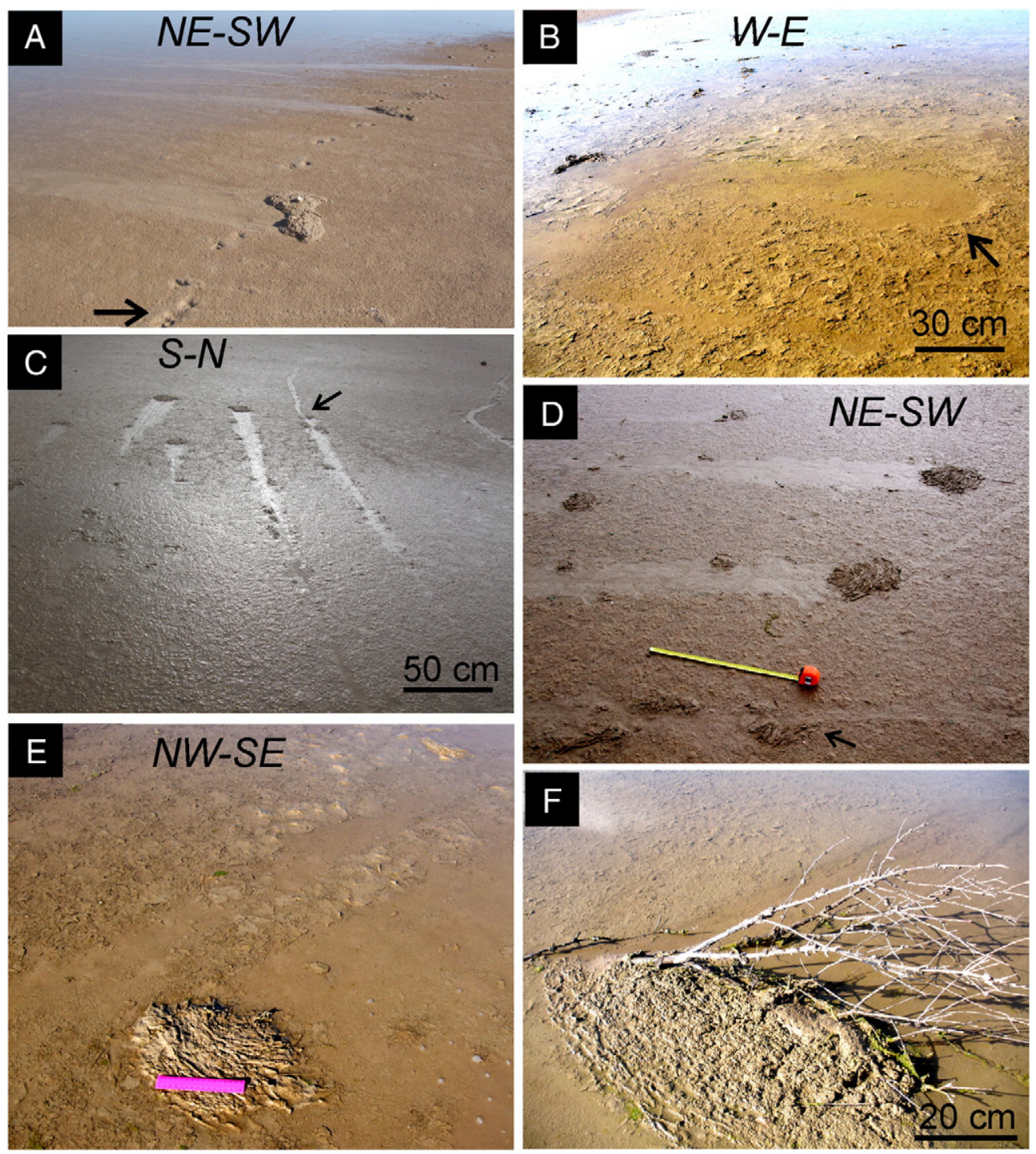

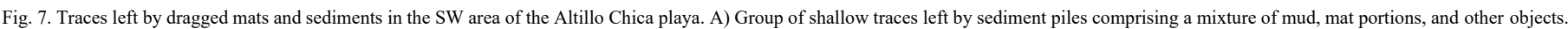

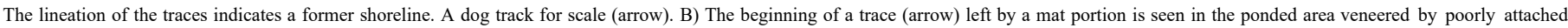
mats. C) Group of parallel, cone-shaped paths ending at wrinkled mat piles. Notice that a narrower trace arises from the scar at the right (arrow).

D) Close-up view showing the beginning of a rock track (arrow) and the lateral branching at the ending of the wrinkled mat tracks. Tape measure is $50 \mathrm{~cm}$ long. E) End of a smooth

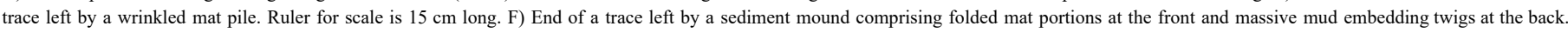

with many small holes distributed randomly throughout (Fig. 8A-C). Sitz marks with similar steep edges are also recognisable in intermediate positions along the paths (Fig. 8D-F). The sitz marks show how deep a rock was embedded before moving. The rock bases are commonly greenish and show signs of etching, which is the result of having been embedded in saturated mud with cyanobacteria. On either side of the tracks, there are asymmetrical levees up to $2 \mathrm{~cm}$ high, and irregular piles of mud presumably expelled by the rock as it travelled underwater (Fig. 8E-F). Along the track itself there are shallow striations that reflect the edges of the object that moved along it (Fig. 8D-E). The striations, however, may change in morphology and depth or even disappear in some stretches. Commonly, the tracks change in morphology and orientation (Figs. 2A, 8F), this could indicate that the objects moved episodically.

The rocks can occur in groups that leave similar traces (or signatures, as defined by Stanley, 1955) showing perhaps synchronous movement (Figs. 2A, 6A, $8 \mathrm{E})$. Tracks commonly cross one another, so that the intertrack separations may vary from a few $\mathrm{cm}$ to $1 \mathrm{~m}$. The dimensions of corresponding reaches within tracks of similar appearance are generally not the same (Fig. 8E). There are striking similarities in the signatures of neighbouring furrows, despite differences in morphologies and lithologies (Fig. $8 D$ ), which suggest that weight is not the main controlling factor. Single stones could respond to an episode of movement not recorded by other nearby stones. A group of traces commonly cut at different angles, previous grooves (Fig. 2A).

The composition of the sediment on which trails are carved is summarised in Table 2E-F. In general, the content in detrital silicates increases from the outset (Table 2E) to the end of the tracks, whereas the gypsum crystals decrease (Table 2F). The organic $\mathrm{C}$ content in the sediment forming the playa substrate (less than $0.9 \%$ ) is significantly lower than in the overlying microbial mat (Table $2 \mathrm{~B}-\mathrm{C}$ ). The submerged stretches of the trails seem to have been rapidly colonised by a green biofilm (Fig. 8B-C).

At the end of the tracks, the stones and the dragged mats and sediment mounds generally overlap (Figs. 8A-B, 10). Mounds of varying volumes are generally embedding the stones and it is not uncommon to 

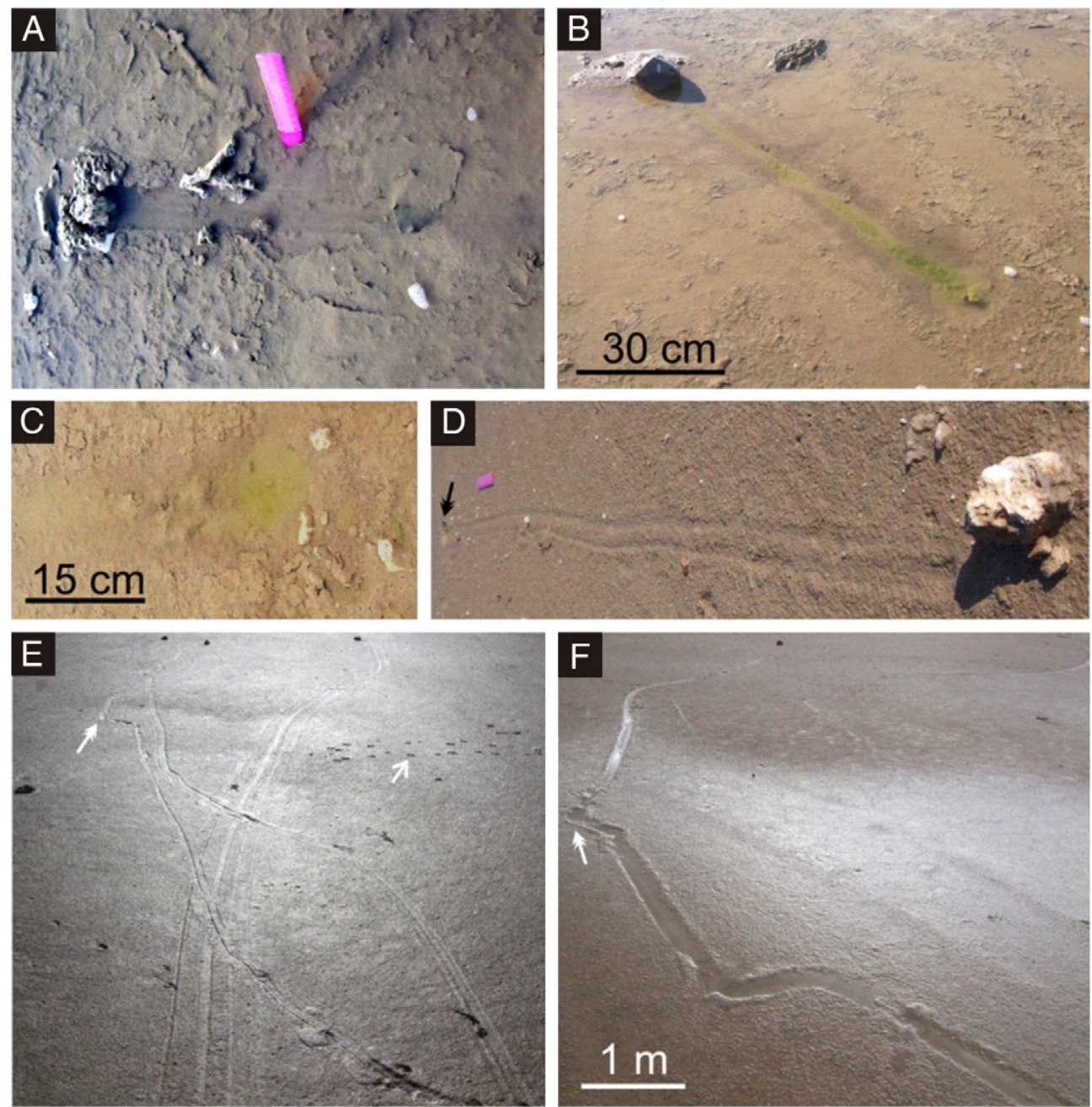

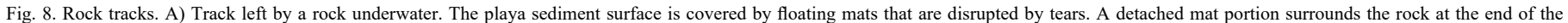

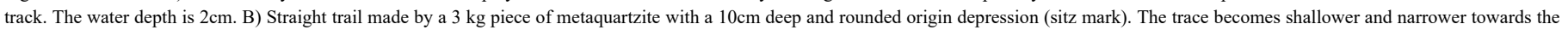

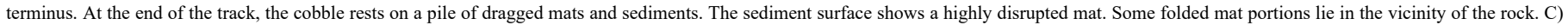

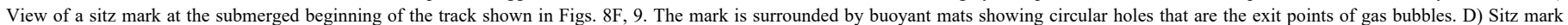

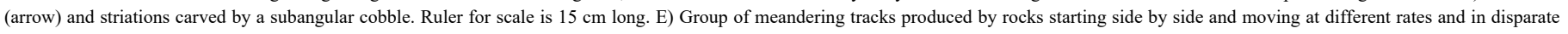

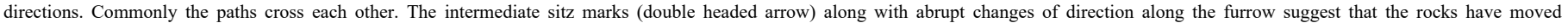
episodically. A dog track (arrow) separates two generations of rock tracks. F) View of the end segments of the trace left by a rock shown in Fig. 9.

find the rocks lying totally or partially on the mat wrinkled piles (Fig. 10A) and massive sediment (Fig. 10B-D). The track width left by stones embedded by the sediment mounds can change lengthwise and is commonly narrower than the stone itself (Fig. 10C). Some furrows may disappear in some parts of the tracks, generally in the final stretches (Fig. 10B). In addition, some rocks on the transported mats simply have left no trace (Fig. 10A, D). One stone had the origin of its trail just at the end of a mat wrinkled pile (Fig. 7D). Sediment mounds deposited in previous events may have interfered with the movement of rocks that followed close paths to them (Fig. 10B-C). The piles deposited around the stones consist of a mixture of detached mat portions, small stones, uprooted herbs, and/or twigs (Figs. 8A-B, 10).

The mineralogical, textural, and structural properties of the folded matbearing a rock on its top (Fig. 10A) were examined under SEM (Fig. 11) a ndby DRX (Table 2G). Structurally, the dragged mat portion consists of a tangle-patterned of filaments and diatoms that bind the mineral grains together, clearly increasing the strength of the mat. The mineral fraction consists of corroded gypsum crystals (48\%), up to $200 \mu \mathrm{m}$ in size, phyllosilicate clays $(13 \%)$ and calcite $(12 \%)$. Silt-sized, quartz and feldspar grains abound (27\%) in the mat piles.

\section{Discussion}

These results support that microbial mats play a role in stone movement across playa lake surfaces and provide evidence for the origin of the trails under the influence of strong winds generating water currents or traction.

\subsection{Environmental conditions}

With direct observations carried out when the traces were newly formed, the physical, biological and geochemical properties of both sediment and water that affect sediment erodibility (Grabowski et al., 2011) were preserved in great detail. In addition, with the associated sedimentary structures undisturbed, the conditions of formation could be more precisely defined. The data on optimal meteorological conditions for these processes supplied a comprehensive record of direct and indirect factors that favoured the movement of the rocks and the associated sediment. The diagram in Fig. 12 summarises the conditions of formation of the tracks and the sedimentary structures found on the Altillo Chica playa. 


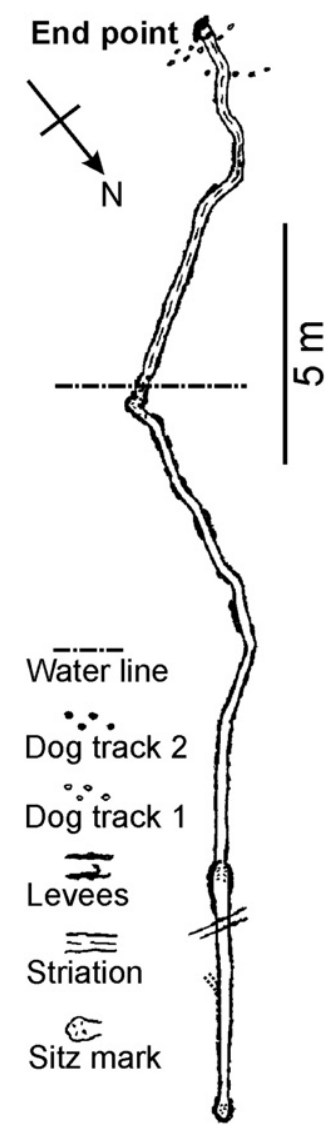

Fig. 9. Sketch of the complete stone track shown in Fig. $8 \mathrm{C}$ and F (see text for explanation).

Our results indicate that each track originates subaqueously on a slippery and bubble-rich floor covered with a microbial mat layer that is floating or poorly attached to the substrate and terminates on the shoreline at a stone, and/ or a mound. The mounds mostly consist of patches of detached and folded mat and variable amounts of the underlying sediment. The resulting sedimentary assemblage found at the end of the traces includes wave-formed ripple marks and roll marks that are sign of a flow of water that had enough energy to cause motion of the objects (Boggs, 2009). In addition, the elongate line of the scrapers arranged on the littoral area close to this group of sedimentary structures indicates the position of the edge of the water when the lake was fuller.

A variety of mat deformation structures (Gerdes et al., 1993; Schieber et al., 2007), including tears, flipped-over edges, rip-up clasts, folds, and wrinkled mat piles are associated with the stone tracks. It is well established that breakage of shrinkage cracks during long lasting dry season favours the development of mat deformation structures (Eriksson et al., 2007; Bouougri and Porada, 2012). Mat deformation structures develop during strong, episodic storms and are due to water or wind friction acting upon floating or loosely attached microbial mats (Fagerstrom, 1967; Gerdes et al., 1993; Schieber, 1999; Bouougri and Porada, 2012). Gases produced from microorganisms below the upper mat may accumulate in bubbles and favour the flotation and trans-portation of mat fragments by currents (Hagadorn and Mcdowell, 2012). According to Noffke (2010), the critical shear stress velocity for erosion of epibenthic microbial mat must be higher than $1.6 \mathrm{~m} \cdot \mathrm{s}^{-1}$.

Specifically, the development of oriented folds found in many mounds indicates water-saturated mats and substrate, favouring the soft-deformation of the detached mat along a slippery mat-sediment interface (Bouougri and Porada, 2012).

Along these lines, the suite of the distinctive sedimentary structures associated with the rock trails in the Altillo playa-lake provides persuasive evidence for the origin of the trails under the influence of strong winds generating water currents or traction in shallow flooded areas and/or acting directly on water-saturated mat surfaces. The orientation of both trails (Fig. 3A) and sedimentary structures is coherent with the changing prevailing winds and the direction of wind in gusts recorded during the water and wind storms occurred throughout the area during the second week of November 2012 (Fig. 3B). For this period, the gusts of wind reached $15.5 \mathrm{~m} . \mathrm{s}^{-1}$ (9 November). Thus, the rocks moved episodically within a period of one week. After that week, strong episodes of wind of variable directions have been recorded over the area. It was tested that even the strong winds and heavy precipitation, typical of an explosive cyclogenesis event, did not blow the rocks from its new location, where microbial mats were absent. Thus, wind-driving of individual stones across wet playa surfaces is not the main factor involved in rock transportation, as suggested by a group of authors (see references above). Instead, the observed lack of movement reinforces the influence of microbial mats in the erosion threshold of the rocks.

Along the same terms, movement of the objects by ice, as invoked by some authors (Stanley, 1955; Reid et al., 1995; Lorenz et al., 2011) i s ruled out because water freezing does not occur at the negative temperature values recorded in the area. As additional evidence, similar pairs of tracks cross one another (Fig. 8E). As noted by Sharp and Carey (1976), the stones that are transported by an ice sheet should maintain constant separation. It is also discarded that the surface runoff has moved the rocks, as suggested by Wehmeier (1986). In the Altillo Chica playa the watershed runoff is dominated by subsurface processes and moves towards the centre of the lake. The tracks are oriented in the opposite direction.

\subsection{Influence of buoyant microbial mats in erosion threshold}

The rock trails are only produced in the areas of the playa covered with microbial mats at the Altillo Chica playa. The selective occurrence of the tracks, along with a number of features, including overlapping, orientation of trails and common origin areas, not only gives evidence of synchronised motion of stones and mat portions but also links genetically the two structures.

In turn, the prevailing presence of cohesive microbial mats in the origin, along the trail and, at the terminus of the rock tracks, as seen in the Altillo Chica playa, indicates that the microbial mats play a role in stone movement. This is consistent with the investigations on sediment-hosting microbial mats that concluded that significant trends in erosion threshold and rate are strongly biofilm dependent (Montague et al., 1993; Sutherland et al., 1998; Grabowski et al., 2011; Vignana et al., 2012). EPS excreted by cyanobacteria and benthic diatoms for purposes of motility and attachment appear to possess very cohesive physical properties. Cohesive mats may contribute to sedimentbinding and stabilisation when bubbles do not form (Montague et al., 1993; Sutherland et al., 1998). On the contrary, gas blistering of the cohesive upper laminated part of the mat producing many random bubbles in the sediment is likely to destabilise the underlying sediments (Montague et al., 1993). These authors suggest that trapped gas bubbles in the mat are responsible for positively buoyant, bulk density values of the sediment. The overlying microbial mat prevents this low bulk density fluff layer from floating. While the upper veneer of the mat could withstand moderate stirring energy, when its breaking point is achieved, it can break away suddenly, exposing bubbleseparated sediments below, which are more easily eroded. Similarly, Hagadorn and Mcdowell (2012) record that aggregated sediment grains are removed and transported by a flow concomitant with, or immediately after, removal of the surface layer of microbial mats. Analogous re-sponses to buoyant biofilms have been observed in studies of clay-sized sediment (Droppo et al., 2007; Tolhurst et al., 2008). The fragmen-tation of the microbial upper layer, the subsequent destabilisation, and transportation of the underlying sediment may explain the presence 

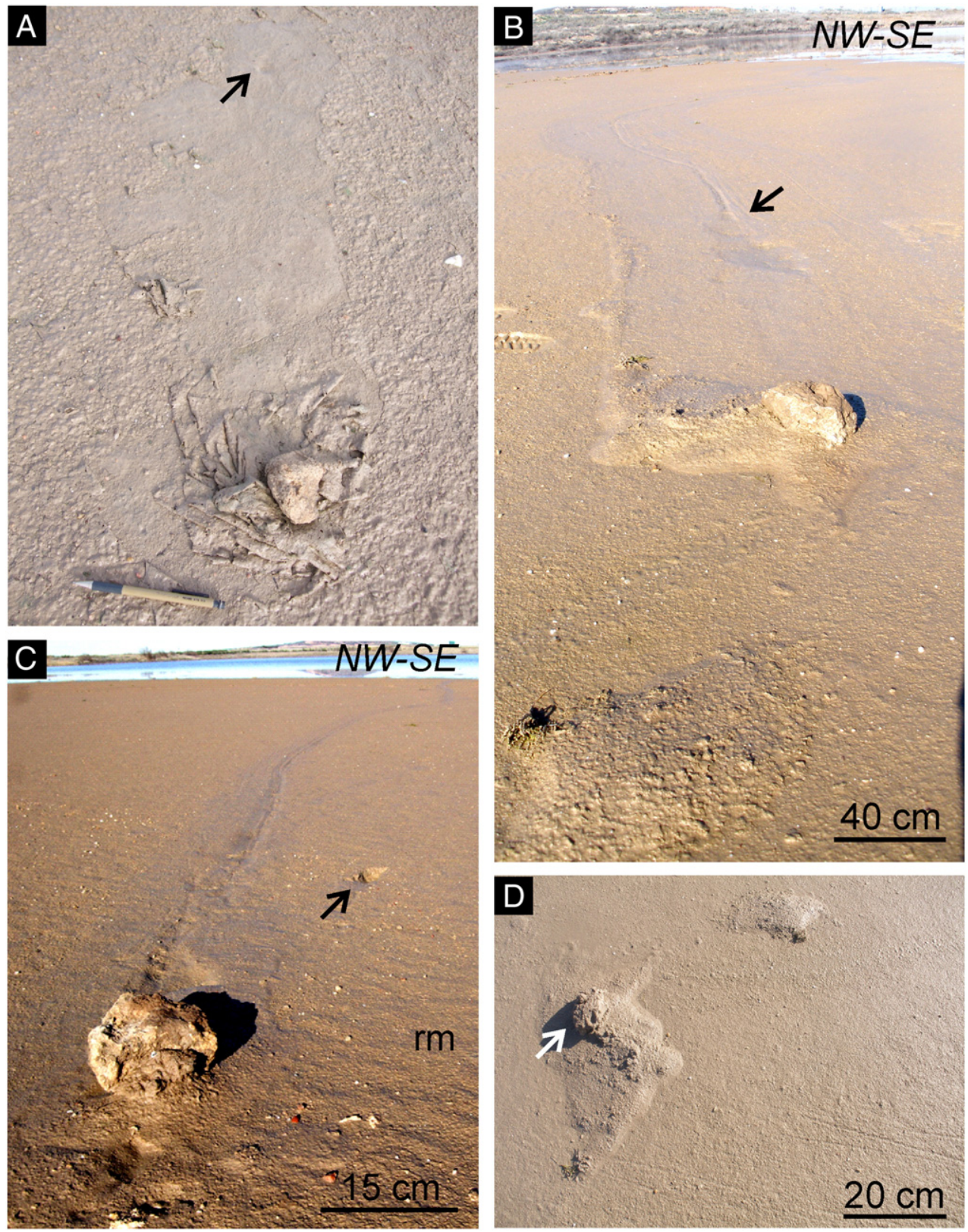

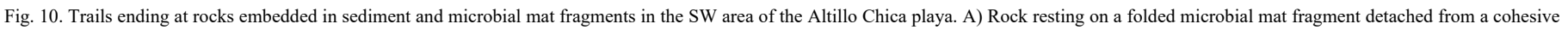

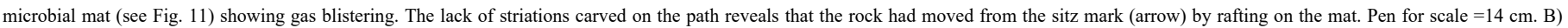

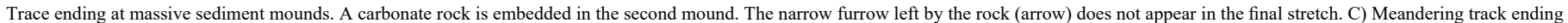

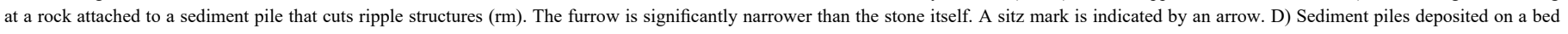
showing furrows previously carved by pebble-sized stones. A chert rock rests on a mound (arrow).

of the sediment piles (Fig. 10) that are associated with the detached portions of mats (Fig. 7F) in the littoral area of the Altillo Chica.

The sudden exposure of bubble-separated sediment is also envis-aged as a plausible source of buoyancy required to lift up the rocks at the starting point (sitz mark) and to reduce the normal force on the base of the rock before being dragged horizontally. This catalyst mechanism is further consistent with the presence of porous sediment around the sitz marks (Fig. $8 \mathrm{~B}-\mathrm{C})$ and throughout the SW area of the Altillo playa.

The ubiquitous presence of sediment along the tracks and the partial or total overlapping of the rocks with the mud mounds at the end points reveal that rocks were transported into the shore embedded in sediment masses (Fig. 10). A sediment raft forming around the rock may allow it to be more easily dragged by the flow.
The discrepancies in size between the tracks and the transported object, the shallow striations of the trails and the lack of track itself further support the argument that the objects were rafted in by buoyant mat fragments and/or by the attached underlying sediment. The formation of rafts allows the rocks to spread out their weight over a wider area, enabling the wind-induced currents to move them more easily. The idea that rocks were enclosed and transported by ice rafts was first invoked by Stanley (1955) at the Racetrack near Death Valley. Later, Reid et al. (1995) and Lorenz et al. (2011) provided additional data to support the rafting mechanism. Although the involvement of ice is discounted at the Altillo Chica playa, our observations reinforce the importance of the rafting mechanisms in the transportation of rocks. The development of microbial mats and mat deformation structures is common in the playas hosting sliding rocks (Clements, 1952; Kirk, 


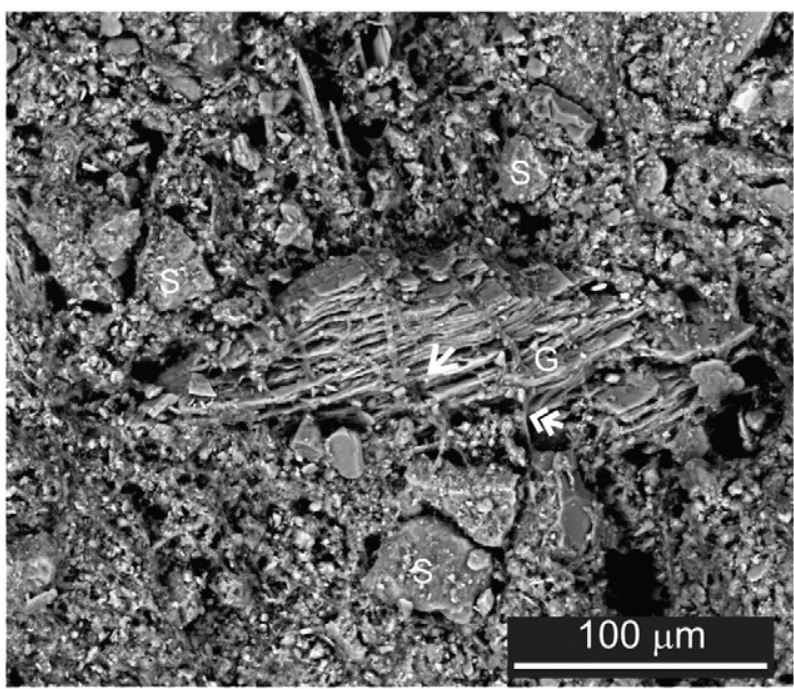

Fig. 11. SEM-ESEM image of a folded microbial mat from the SW area of the Altillo Chica playa (see Fig. 10A). It shows that the detrital grains (S) and mineral precipitates (mainly gypsum, G) are held by elastic mucus threads (double-headed arrow) and the associated diatoms (arrow).

1952; Shelton, 1953; Sharp and Carey, 1976; Messina, 1988), although only some authors have recognised that the microbial mats play a role in the movement of the rocks as a lubricant (Shelton, 1953; Messina, 1988; Lorenz et al., 2011).

Altillo Chica playa can be extrapolated to other playa-lakes where the phenomenon is also observed. Observations of drifting sediment with attached rocks in the Altillo Chica playa provide a better understanding of the debated mechanisms which drives the rocks and enhance the role of the microbial sediments in the movement of the rocks. In addition, results give insight into the formation of sedimentary structure assemblages following strong events of wind and water in playa mudflats.

Moving from the actualistic viewpoint to the rock record, different authors have documented the potential of many microbial signatures, including tool marks, to become fossilised (Beukes, 1996; Schieber, 1999; Schieber et al., 2007; Eriksson et al., 2000; Gerdes et al., 2000; Bouougri and Porada, 2002; Noffke, 2010. The preservation of these structures requires rapid bacterial biostabilisation and/or sediment burial. Instead, the preservation potential of the rock tracks seems to be low, because later rain episodes would erase them. However, the association of coarse and exotic stones with microbial-mat related structures has potential to be preserved, this providing strong indicators of storm events in mudflats.

\section{Conclusions}

The occurrence of rock tracks on the Altillo Chica playa lake (central Spain) expands the distribution of these sedimentary structures and suggests that the movement of rocks on flat surfaces is a geographically widespread phenomenon.

The tracks are temporally and spatially associated with microbial mats that show a variety of mat deformation structures. In the origin area of the tracks, the presence of buoyant microbial mats and bubbling sediment is likely to have a significant effect in sediment destabilisation.

Available objects including large stones can move across slippery flat surface, under the influence of wind-generated water currents if they are embedded by buoyant microbial sediments that act as a catalyst for moving activity and reduce the mechanical friction. The distribution of the rocks' weight over sliding sediment rafts may allow the rocks to be more easily propelled.
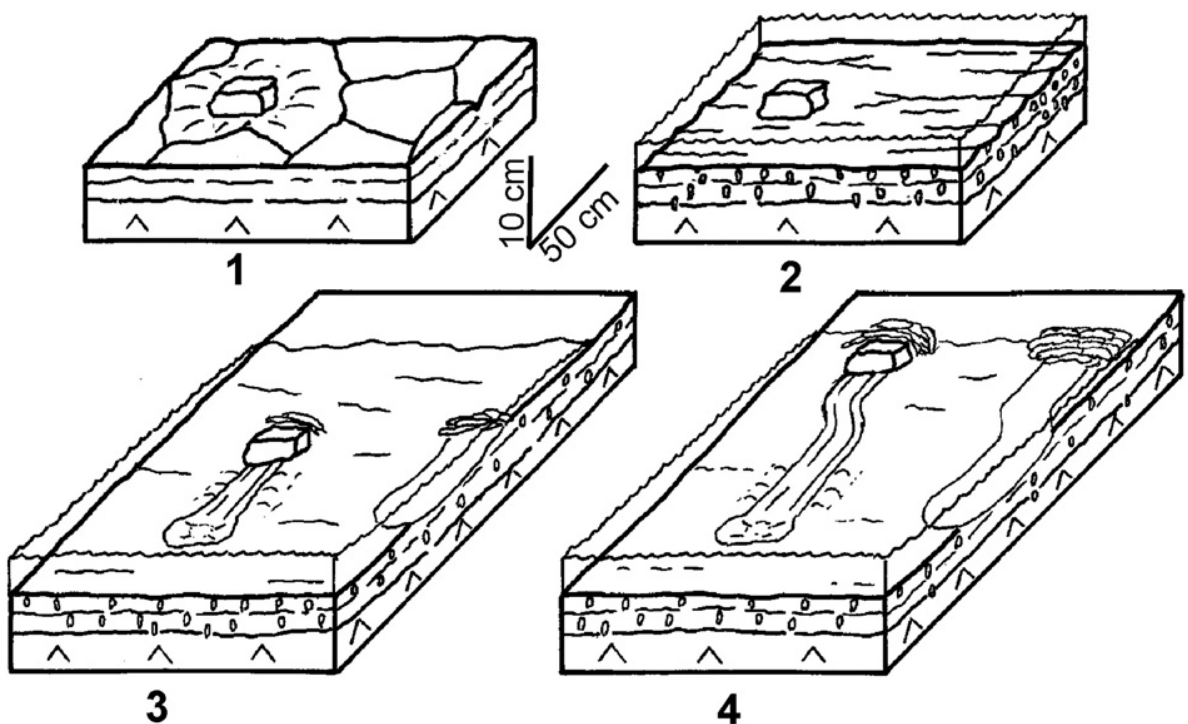

3

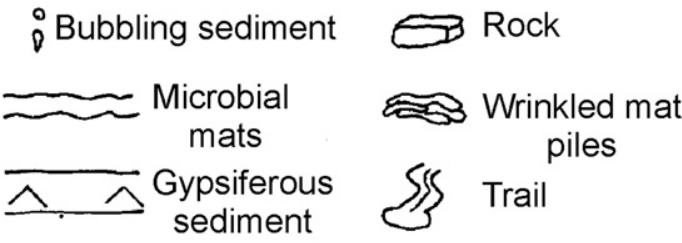

Water lamina

$\sim$ Ripples

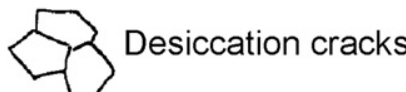

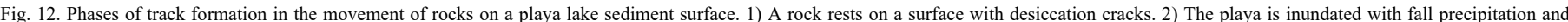

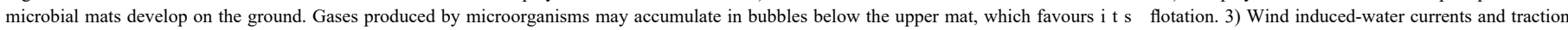

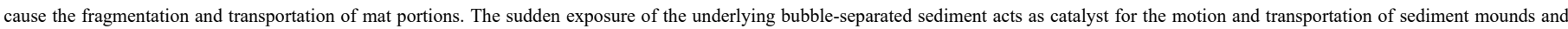
attached rocks by a flow. 4) The trails that objects have left behind end at the water's edge. 
The assemblage of variably-sized stones and microbial-mat related structures provides a new tool for inferring past storm episodic events in playa mudflats.

\section{Acknowledgements}

This research work has been funded by the national project CGL2011-26781 (Spanish Ministry of Economy and Competivity). The work is part of the scientific activities of Research Group - 910404 (Complutense University of Madrid). We gratefully acknowledge the constructive comments of Dr. Gierlowski-Kordesch and an anonymous reviewer. MESM is grateful to Dr. Villaroya who once spoke about this topic by chance.

\section{References}

Bacon, D., Cahill, T., Tombrello, T.A., 1996. Sailing stones on Racetrack Playa. The Journal of Geology 104, 121-125.

Bauld, J., 1981. Occurrence of benthic microbial mats in saline lakes. Hydrobiologia 81 , $87-111$.

Beukes, N.J., 1996. Sole marks and combined-flow storm event beds in the Brixton Formation of the siliciclastic Archean Witwatersrand Supergroup, South Africa Journal of Sedimentary Research 66, 567-576.

Boggs, S., 2009. Petrology of Sedimentary Rocks. Cambridge University Press, Cambridge, UK, (600 pp.).

Bouougri, E.H., Porada, H., 2002. Mat-related sedimentary structures in Neoproterozoic peritidal passive margin deposits of the West African Craton (Anti-Atlas, Morocco). Sedimentary Geology $153,85-106$.

Bouougri, E.H., Porada, H., 2012. Wind-induced mat deformation structures in recent tidal flats and sabkhas of SE Tunisia and their significance for environmental interpretation of fossil structures. Sedimentary Geology 263-264, 56-66.

Clements, T., 1952. Wind-blown rocks and trails of Little Bonnie Claire Playa. Journal of Sedimentary Petrology 22, 182-186.

Di Cesare, F., Pratelli, W., 1967. "Moving stones" of the Tunisian Sahara (Bir Pistor). In Martin, L. (Ed.), Petroleum Exploration Society of Libya, 9th annual field conference, guidebook to the geology and history of Tunisia. Guidebook to the Geology and History of Tunisia 66, p. 273

Droppo, I., Ross, N., Skafel, M., Liss, S., 2007. Biostabilization of cohesive sediment beds in freshwater wave dominated environment. Limnology Oceanography 52, 577-589. Eriksson,

P.G., Foertsch, E.B., Snyman, C.P., Lingenfelder, J.H., Beukes, B.E., Cloete, W., 1996 Wind-blown rocks and trails on a dry lake bed; an alternative hypothesis. Journal of Sedimentary Research 66, 36-38.

Eriksson, P.G., Simpson, E.L., Eriksson, K.A., Bumpy, A.J., Steyn, G.L., Sarkar, Sl, 2000. Muddy roll-up structures in siliciclastic interdune beds of the c. $1.8 \mathrm{Ga}$ Waterberg Group, South Africa. Palaios 15, 177-183.

Eriksson, P.G., Porada, H., Banerjee, S., Bouougri, E., Sarkar, S., Bumby, A.J., 2007. Matdestruction features. In: Schieber, J., Bose, P.K., Eriksson, P.G., Banerjee, S., Sarkar, S., Altermann, W., Catuneau, O. (Eds.), Atlas of Microbial Mat Features Preserved within the Siliciclastic Rock Record, Atlases in Geology 2. 4 (c). Elsevier B.V., Amsterdam, pp. 5 38.

Fagerstrom, J.A., 1967. Development, flotation, and transportation of mud crusts neglected factors in sedimentology. Journal of Sedimentary Petrology 37, 73-79. Gerdes, G.,

Claes, M., Dunajtschik-Piewak, K., Riege, H., Krumbein, W.E., Reineck, H.E., 1993. Contribution of microbial mats to sedimentary surface structures. Facies 29, 61-74

Gerdes, G., Klenke, T., Noffke, N., 2000. Microbial signatures in peritidal siliciclastic sediments. A catalogue. Sedimentology 47, 279-308.
Grabowski, R.C., Droppo, I.G., Wharton, G., 2011. Erodibility of cohesive sediment: the importance of sediment properties. Earth-Science Reviews 105, 101-120. Guerrero, M.C.

De Wit, R., 1989. Microbial mats in the inland saline lakes of Spain. Limnetica 8, 197-204.

Hagadorn, J.W., Mcdowell, C., 2012. Microbial influence on erosion, grain transport and bedform genesis in sandy substrates under unidirectional flow. Sedimentology 59 , 795-808.

Kirk, L.G., 1952. Trails and rocks observed on a playa in Death Valley National Monument, California. Journal of Sedimentary Petrology 22, 173-181.

Lines, G.C., 1979. Hydrology and surface morphology of the Bonneville Salt Flats and Pilot Valley Playa, Utah. Geological Survey Water-Supply Paper.United States Government Printing Office, Washington, D.C.

Lorenz, R.D., Jackson, B.K., Barnes, J.W., Spitale, J., Keller, J.M., 2011. Ice rafts not sails: floating the rocks at Racetrack Playa. American Journal of Physics 79, 37-42.

Messina, P., 1988. The Sliding Rocks of Racetrack Playa, Death Valley National Park, California. City University of New York (Ph.D. Thesis, available at geosun.sjsu.edu/ paula/rtp/dissertation/toc.htm).

Messina, P., Stoffer, P., 2000. Terrain analysis of the Racetrack Basin and the sliding rocks of Death Valley. Geomorphology 35, 253-265.

Montague, C.L., Paulic, M., Parchure, T.M., 1993. The stability of sediments containing microbial communities: initial experiments with varying light intensity. Coastal and Estuarine Studies 42, 348-359.

Noffke, N., 2010. Geobiology: Microbial Mats in Sandy Deposits from the Archean Era to Today. Springer-Verlag, Berlin $194 \mathrm{pp}$.

Noffke, N., Gerdes, G., Klenke, T., Krumbein, W.E., 2001. Microbially induced sedimentary structures - a new category within the classification of primary sedimentary structures: perspectives. Journal of Sedimentary Research 71, 649-656.

Pérez González, M.E., Sanz, J., 1998. Clima y microclima de La Mancha húmeda. 18. Anales de Geografia de la Universidad Complutense 239-256.

Reid, J.B., Bucklin, E.P., Copenagle, L., Kidder, J., Pack, S., Polissar, P., Williams, M.L., 1995. Sliding rocks at the Racetrack, Death Valley: what makes them move? Geology 23, 819-822.

Sanz-Montero, M.E., García del Cura, M.A., Rodríguez-Aranda, J.P., Calvo, J.P., 2012. Tapices microbianos y estructuras sedimentarias asociadas en sistemas deposicionales evaporíticos de La Mancha: un enfoque actualista. Geotemas 13, 167-170.

Sanz-Montero, M.E., Calvo, J.P., García del Cura, M.A., Ornosa, C., Outerelo, R., RodríguezAranda, J.P., 2013. The rise of the diptera-microbial mat interactions during the Cenozoic: consequences for the sedimentary record of saline lakes. Terra Nova 25, 465 471. http://dx.doi.org/10.1111/ter.12058.

Schieber, J., 1999. Microbial mats in terrigenous clastics; the challenge of identification in the rock record (in unexplored microbial worlds). Palaios 14, 3-12.

Schieber, J., Bose, P.K., Eriksson, P.G., Banerjee, S., Sarkar, S., Altermann, W., Catuneau, O., 2007. An Atlas of Microbial Mat Features Preserved within the Siliciclastic Rock Record. Elsevier, Amsterdam (311 pp.)

Sharp, R.P., Carey, D.L., 1976. Sliding stones, Racetrack Playa, California. Geological Society of America Bulletin 87, 704-1717.

Shaw, P.A., Bryant, R.G., 1997. Pans, playas and salt lakes. Arid Zone Geomorphology. Wiley Online Library, pp. 373-401.

Shelton, J.S., 1953. Can wind move rocks on Racetrack Playa? Science 117, 438-439. Stanley,

G.M., 1955. Origin of playa stone tracks, Racetrack Playa, Inyo County. Californian Geological Society of America Bulletin 66, 1329-1350.

Sutherland, T.F., Amos, C.L., Grant, J., 1998. The effect of buoyant biofilms on the erodibility of sublittoral sediments of a temperate microtidal estuary. Limnology Oceanography $43,225-235$.

Tolhurst, T.J., Consalvey, M., Paterson, D.M., 2008. Changes in cohesive sedimen properties associated with the growth of a diatom biofilm. Hydrobiologia 596, 225-239.

Vignana, E., Haynes, H., Sloan, W.T., 2012. Quantifying the tensile strength of microbial mats grown over noncohesive sediments. Biotechnology and Bioengineering 109, $1155-1164$

Wehmeier, E., 1986. Water induced sliding of rocks on playas: Alkali Flat in Big Smoky Valley, Nevada. Catena 13, 197-209. 